\title{
Kontextuellt tänkande om pedagogik
}

\author{
Lennart Svensson
}

I denna artikel betonas behovet av, och möjligheten med, ett kontextuellt tänkande om pedagogik. Kontextuellt tänkande är ett genomgående tema som lyfts fram i inledningen och avslutningen av artikeln. I ett huvudavsnitt om pedagogikens historiska utveckling lyfts två inslag fram, övergången från pedagogik som filosofi till pedagogik som vetenskap, respektive skillnaden mellan en variabelbaserad och en fallbaserad vetenskaplig kunskapsbildning om pedagogik. I ett andra huvudavsnitt diskuteras vad som är pedagogikens kunskapsobjekt, hur pedagogikens kunskapsområde kan avgränsas, samt den institutionella inramningen av pedagogisk forskning. Artikeln avslutas med en sammanfattning av det viktigaste $\mathrm{i}$ det som framförts.

\section{INLEDNING}

En huvudtanke i denna artikel är att pedagogik som fenomen kräver ett kunskapsteoretiskt kontextuellt tänkande för att man skall nå en djupare förståelse av och kunskap om pedagogiken. Denna tanke har hos mig som forskare och författare utvecklats under en lång verksamhet som forskare. Jag började min forskarkarriär under slutet av 1960-talet med en psykometrisk inriktning och användning av och utveckling av statistiska metoder för bearbetning av data som hade en språklig grund. Jag blev upptagen med svårigheten att förutsätta likhet $\mathrm{i}$ innebörd hos språkliga data mellan individer, på det sätt som man gör bland annat vid konstruktion och användning av variabler i test, prov och frågeformulär. Detta intresse för grundläggande antaganden bakom insamling och produktion av språklig data ledde till att jag med intresse följde utvecklingen av områdena lingvistik, psykolingvistik, sociolingvistik och språkfilosofi, när det gäller teorier om språklig mening samt kunskapsteori och vetenskapsteori, särskilt när det gäller forskningsmetodologi. Mot denna bakgrund och i förhållande till 
pedagogikens fenomen har jag kommit fram till vikten av kontextuellt tänkande.

Här i inledningen ges en första bakgrund till och bestämning av vad som menas med kontextuellt tänkande. Vad det kontextuella tänkandet innebär blir sedan ytterligare klargjort genom den fortsatta framställningen om pedagogik. Det kontextuella tänkandet handlar här om att man bestämmer innebörden av pedagogiska fenomen, och särskilt delar av dessa fenomen, som beroende av sitt sammanhang. Motsatsen är definitionsmässiga bestämningar av innebörd, som görs generellt, oberoende av innebördsenheternas specifika sammanhang. Författarens kontextuella tänkande har lett till ståndpunkten att den bästa grunden för kunskapsbildningen är att klargöra vilka kunskapsobjekt som avgränsas i förhållande till sin kontext och tillsammans utgör ett kunskapsområde. När det gäller pedagogikens kunskapsområde har detta kontextuella tänkande lett till fokus på relationen mellan stöd till lärande och lärande som de centrala pedagogiska kunskapsobjekten.

Under det sena 1960-talet och under 1970-talet ökade intresset för och diskussionen om kunskapsteori, vetenskapsteori och forskningsmetodologi inom human- och samhällsvetenskaperna. En stor del av diskussionen handlade om vetenskapliga paradigm. Begreppet paradigm diskuterades bland annat av Kuhn (1962/1970, 1970, 1974), Masterman (1970) och många andra. Vid Göteborgs universitet, där författaren till denna artikel var verksam, var Håkan Törnebohm professor i vetenskapsteori (1963-1985). Törnebohm $(1975,1977 \mathrm{a}, 1977 \mathrm{~b})$ diskuterade också begreppet paradigm. Hans intresse gällde hur man kan bestämma vad ett paradigm är. Han analyserade och beskrev paradigm som komplex av olika faktorer. Han fann att paradigm utgjordes av två huvudfaktorer $\mathrm{i}$ relation till varandra, ontologi och metodologi (strategi).

Mycket av intresset för och diskussionen om paradigm gällde skillnader mellan forskningstraditioner och grupperingar av forskning under paradigm. Radnitzky (1970), som samarbetade med Törnebohm, presenterade en omfattande beskrivning av grundläggande skillnader mellan forskningstraditioner. Radnitzky använde inte begreppet paradigm utan diskuterade skillnader mellan "schools of meta-science". Han skilde mellan två överordnade metavetenskapliga skolbildningar, den anglosaxiska och den kontinentala skolan. Distinktionen kommer nära vad som ofta talas om som en skillnad mellan en positivistisk/analytisk tradition och en dialektisk/fenomenologisk/hermeneutisk tradition. Radnitzkys arbete är en historisk beskrivning.

Törnebohm gör, $\mathrm{i}$ sin mer logiska analys, en liknande indelning $\mathrm{i}$ två huvudsakliga grupper av paradigm, som han först kallade 1) taxonomiska och kompositionella paradigm och 2) kontextuella paradigm (Törnebohm, 1977a) och sedan 1) systemiska och 2) kontextuella paradigm (Törnebohm, 1977b). 
Han diskuterade kontextuella strategier, kontextuella analyser och kontextuella synteser som delar av kontextuella paradigm. Det finns stora likheter mellan vad som här menas med kontextuellt tänkande och Törneboms beskrivning. Författaren till denna artikel använde begreppet kontextuell analys före Törnebohms användning av detta begrepp i skrift (Svensson 1976). Den fortsatta beskrivningen $i$ denna artikel tar sin utgångspunkt specifikt $\mathrm{i}$ pedagogikämnet, även om beskrivningen också i vissa delar har mer generell giltighet.

Kontextuellt tänkande diskuteras här som önskvärt för att förstå och beskriva pedagogiska fenomen (se Svensson, 2004; Svensson \& Doumas, 2013). I linje med Törnebohms beskrivning tänks kunskapsbildning om pedagogik bygga på två huvudfaktorer, ontologi och metodologi (strategi). Det handlar här om hur forskaren förstår de pedagogiska fenomenens karaktär respektive hur man bäst kan bilda kunskap om fenomenen. I båda dessa avseenden finns det en principiell skillnad mellan systemiska och kontextuella paradigm. Här handlar det om vad som utgör den mest principiella skillnaden i pedagogiskt tänkande, och att, och varför, kontextuellt tänkande är det önskvärda.

\section{PEDAGOGIKENS HISTORISKA UTVECKLING}

I Europa brukar vi när det gäller pedagogiskt tänkande gå tillbaka till det antika Grekland och till tänkare som Sokrates, Platon och Aristoteles. Det är vanligt än idag att göra hänvisningar till idéer och tankar som presenterades för ca 2400 år sedan. Pedagogikens historia är mycket omfattande och rymmer inom sig samhälls-, grupp-, individ- och kulturperspektiv. Ett vanligt sätt att ange vad pedagogik som ämne handlar om har varit att säga att pedagogiken handlar om uppfostran, undervisning och utbildning. Dessa tre ord betecknar tre typer av aktiviteter och verksamheter, som tänks vara pedagogiska.

Det finns en omfattande litteratur om pedagogikens historia och idéhistoria fram till pedagogikens etablering som vetenskap. Sjöstrand (1954-1965) beskriver pedagogikens utveckling från antikens Grekland och i Europa samt utvecklingen i Sverige fram till 1920-talet. Landquist (1963) ger också en beskrivning av samma historiska utveckling och går lite längre fram i tiden. Sjöstrand (1969), Sandström (1975) och Myhre (1967, 1988) ger mer renodlat idéhistoriska beskrivningar av pedagogikämnets utveckling. Ödman (1987, 1990) beskriver utvecklingen i Sverige under 1600- och 1700-talen. Ödman (1995) ger en beskrivning av svensk mentalitets- och pedagogikhistoria. Kroksmark (2011b) beskriver utvecklingen av didaktiska idéer från Comenius på 1600-talet i Tyskland och i Sverige fram till 1980-talet. Kroksmark (2011a) presenterar ett urval av tjugofyra pedagogiska tänkare fram till vår tid. Detta är endast några exempel från en omfattande litteratur. 
En samlad beskrivning av den senare historiska utvecklingen av pedagogik som vetenskapligt kunskapsområde finns inte på samma sätt, som för den tidigare utvecklingen som ämne. Detta beror främst på den stora expansionen av forskningen $i$ kombination med en ökande specialisering. Det finns många handböcker och ett stort antal tidskrifter, som är mer eller mindre specialiserade till pedagogikens många delområden. En serie handböcker som täcker in en ganska stor del av ämnets internationella utveckling är fyra "Handbook of research on teaching" av Gage (1963), Travers (1973), Wittrock (1986) och Richardson (2001). Richardson (2004) ger en beskrivning av den svenska utbildningens historia fram till och in på 2000-talet med fokus på skolpolitiken. Lindberg och Lindberg (1983) och Lindberg och Berge (1988) beskriver den svenska utvecklingen av det akademiska ämnet pedagogik. En utvärdering från HSFR ger en god helhetsbild av den svenska pedagogiska forskningen (Rosengren \& Öhngren, 1997). En introduktion till pedagogikens kunskapsområde ges av Svensson (2014).

\section{Från filosofi till vetenskap}

Utvecklingen under 1600-talet av ett empiriskt grundat vetenskapligt tänkande har haft avgörande betydelse för det pedagogiska tänkandet. Tidigare hade man sett på det som kan iakttas med våra sinnen, som något som måste underordnas teologiska och filosofiska utgångspunkter och tankesystem, och inte som en primär källa till kunskap (även om redan Aristoteles betonade att sinnesintryck är grunden för kunskap). Filosofer som argumenterade för empiriskt grundad kunskap drog också pedagogiska slutsatser av sin kunskapssyn. Den mest kände av dessa är John Locke och ett av hans arbeten, som publicerades på svenska 1693, med titeln Tankar om uppfostran (se Sjöstrand, 1954 och Landqvist, 1963).

Johan Amos Comenius kan anses vara 1600-talets mest framstående pedagogiska tänkare (se Kroksmark, 2011a, 2011b). Han var också nära knuten till utvecklingen av det svenska utbildningsväsendet. Comenius stora verk, Didactica Magna, (Comenius, 1989) illustrerar den filosofiska traditionen att utveckla ett omfattande, heltäckande tankesystem. Undertiteln var på svenska "En fullständig framställning av konsten att lära alla allt". Framställningen handlar om hur uppfostran skall gå till från när barnet är litet i hemmet, sedan i skolan, och genom hela livet. Comenius representerar samtidigt den empiriskt inriktade synen på kunskap, när det gäller människors kunskapsbildning genom pedagogik. Han utarbetade en induktiv metod för undervisning, som tog sin utgångspunkt i det direkt observerbara, och gick från det enkla till det sammansatta.

Under 1700-talet fick de pedagogiska frågorna betydligt större utrymme i samhällsdebatten och ett flertal pedagogiska teoretiker framträdde. Rousseau betonade hänsynen till barnets natur, att behandlingen av olika ämnen måste anpassas till anlagens naturliga utveckling samt betydelsen av åskådning och 
självverksamhet. En annan 1700-talspedagog inspirerad bland annat av Rousseau var Pestalozzi. Han ville upphöja uppfostringskonsten till vetenskap och utvecklade en omfattande pedagogisk praktisk verksamhet, liksom ett pedagogiskt tänkande i både samhälls- och individperspektiv (se om Rousseau och Pestalozzi i Sjöstrand, 1954; Landqvist, 1963; Kroksmark, 2011b).

En pedagogisk rörelse av relativt stor omfattning under 1700-talet var filantropismen. Rörelsen byggde på upplysningens idéer om nytta, förnuft och lycka och hade ett starkt intresse för teoretiska frågor. Lärares behov av teoretiska kunskaper om uppfostran och undervisning uppmärksammades, vilket ledde till inrättandet av den första professuren i pedagogik i Tyskland 1779 vid universitetet i Halle. Den förste innehavaren var Ernst Christian Trapp och hans arbete syftade till att åstadkomma en teoretisk pedagogik grundad på experimentalpsykologisk kunskap (se om filantropismen och Trapp i Sjöstrand, 1954). Under 1800-talet frigjorde sig psykologin alltmer från filosofin, närmade sig naturvetenskapen, och blev mer empirisk och experimentell. Inom pedagogiken väcktes stora förhoppningar om framsteg genom den experimentella psykologin.

Under tidigt 1800-tal föreläste många professorer i filosofi i pedagogik. Immanuel Kant och hans kollegor vid universitetet i Königsberg föreläste i pedagogik. Johann Friedrich Herbart efterträdde Kant som professor i filosofi och pedagogik 1809. Herbart kom att ägna särskild uppmärksamhet åt pedagogiken som ämne, och hans syn på pedagogikämnet fick stor betydelse för utvecklingen av ämnet. Enligt Herbart (1917) skall pedagogikämnet grundas på psykologisk kunskap och därutöver, när det gäller att fastställa målen för uppfostran och undervisning, i etiken. Fram till början av 1800-talet fanns pedagogik alltså som ett område inom filosofin. Från slutet av 1700-talet började professurer i pedagogik som ett från filosofin fristående ämne inrättas först $\mathrm{i}$ Tyskland och sedan $\mathrm{i}$ andra europeiska länder. I nuvarande Sverige skedde detta först i början av 1900-talet.

Utvecklingen från filosofi till empirisk vetenskap utgjorde en genomgripande förändring $\mathrm{i}$ utvecklingen av pedagogik som kunskapsområde. Kunskapsbildningen om pedagogik förändrades. Inom filosofin handlade kunskapsbildningen om att utveckla tankesystem om pedagogik. Inom vetenskapen handlade det om att undersöka den praktiska pedagogiken. De filosofiska tankesystemen var principiella och normativa. De handlade om hur pedagogiken, eller någon del av den, i princip fungerade och borde utformas. Genom den vetenskapliga pedagogikens inriktning på empiriska undersökningar begränsades vad kunskapsbildningen $i$ varje enskild undersökning omfattade. I det vetenskapliga arbetet lades resultat från olika undersökningar samman på ett huvudsakligen kompletterande sätt. En kumulativ kunskapsutveckling med ökande specialisering, beroende på vad som undersöktes, kom till stånd. 
När pedagogik växte fram som ett eget vetenskapligt område fanns det en dominerande syn på vetenskap, inspirerad av framgångarna inom naturvetenskap. Denna syn innebar en betoning av objektiva observationer och systematisk sammanställning av fakta. Den experimentella psykologin framstod som ett ideal för pedagogiken. Under tidigt 1900-tal utvecklades den empiriskt inriktade pedagogiskt psykologiska forskningen allt mer. Denna inriktning kompletterades med historisk och komparativ pedagogik, som behandlade pedagogiska tänkare och system genom historien, liksom den aktuella situationen i olika länder. Den tidiga empiriska forskningen hade också till stor del en didaktisk inriktning med fokus på undervisning och lärande. Även om denna forskning var inspirerad av ett experimentellt tänkande var den till stor del kvalitativt beskrivande av hur elever löste uppgifter och lärde sig ämnesinnehåll.

När pedagogiken blev en egen vetenskap fanns en betoning av definition av teoretiska begrepp, men de skulle också definieras operationellt i sitt empiriska sammanhang och sin användning. Kunskapen skulle utvecklas induktivt med utgångspunkt från gjorda empiriska observationer som skulle systematiseras till teoretisk kunskap. Den starka induktiva inriktningen generellt inom vetenskapen blev ifrågasatt, särskilt av Popper (1959, 1963), som föreslog en hypotetisk deduktiv ansats, som passar särskilt bra $i$ experimentell forskning. Både den induktiva och den deduktiva inriktningen i pedagogisk empirisk forskning har det gemensamt att fokus är på observationer som grund för kunskapsbildning. De har också det gemensamt att dessa observationer i regel görs i form av kategorier/värden i variabler. De begrepp som definieras och utgör utgångspunkt har i allmänhet karaktären av generella variabler. Systematiseringen av observationerna sker $\mathrm{i}$ form av jämförelser av variabelvärden och kombinationer av variabelvärden (se Gage, 1963). Två variabelgrundade traditioner dominerade, en kvasiexperimentell och en beskrivande korrelationell, beskrivna bland andra av Cronbach (1957). Även om denna forskning utgår från empirin bygger den inte på kontextuellt utan på systemiskt kompositionellt tänkande.

\section{Variabel- eller fallbaserade beskrivningar}

I det följande ges en beskrivning av den dominerande variabelbaserade forskningen i termer av vad variablerna har gällt, följt av en beskrivning av en förändring från dominans för variabelbaserad forskning till ökning av en mer kvalitativt beskrivande forskning. Här framställs denna förändring som också en rörelse mot fallbaserade beskrivningar. Fallbaserade beskrivningar ses här som mer fruktbara inom pedagogiken än variabelbaserade beskrivningar och som ett steg $\mathrm{i}$ ett nödvändigt kontextuellt tänkande. Miles och Huberman (1994) beskriver variabelbaserad och fallbaserad forskning som i huvudsak två olika sätt att sammanställa empiriska data. Här fokuseras på en mer grundläggande skillnad mellan variabelbaserad kompositionell (och eventuellt 
fallbaserad) forskning och en fallbaserad kontextuell (och även variationsgrundad) forskning. Det är inte tänkandet om och fokus på variation som ses som problem utan generella definitioner av variabler och variabelvärden oberoende av kontext.

\section{Fokus på beteenden och egenskaper}

Efter andra världskriget kom den engelskspråkiga delen av världen att dominera den internationella pedagogiska forskningen. Inom den engelskspråkiga forskningen skedde en stark utveckling mot dominans för dels behavioristiska synsätt, dels empirisk variabelbaserad forskning med användning av statistiska databearbetningsmetoder. Den för pedagogiken viktiga inlärningsforskningen blev till stor del behavioristiskt inriktad. Individuella differenser och testteori fick också ett stort utrymme. En stor del av forskningen gällde observation och mätning av elevegenskaper som begåvning, kunskaper, färdigheter, attityder och intressen. Denna forskning gällde förutsättningar för och resultat av pedagogiska aktiviteter knutna till elever snarare än till den pedagogiska aktiviteten i sig. Även en forskning om läraregenskaper utvecklades.

Det fanns också tidigt ett mer samhällsteoretiskt perspektiv, särskilt i forskning med anknytning till skolreformer. Denna forskning kombinerade mätning av personegenskaper genom prov, test och frågeformulär med användning av sociala kategorier som socialklass, föräldrars utbildning, bostadsort med flera. Det var i huvudsak en kartläggande forskning av förutsättningar för och resultat av utbildningsinsatser.

Den pedagogiska psykologin omfattade differentialpsykologi, utvecklingspsykologi, inlärningspsykologi och socialpsykologi i anslutning till uppfostran, undervisning och utbildning. Många studier handlade om kartläggning av statistiska samband, korrelationer, mellan individförutsättningar och pedagogiska resultat. Problem med att finna generella samband mellan individuella skillnader $\mathrm{i}$ förutsättningar och individuella skillnader i pedagogiska resultat ledde till studier av interaktioner mellan individvariabler och metodvariabler (undervisningsmetoder) för att bättre kunna predicera och förklara de pedagogiska resultaten (se Bracht, 1970).

\section{Fokus på metoder och yttre och inre processer}

Forskningen om undervisningsmetoder präglades länge av synen på experimentella studier som vägen till säker empiriskt grundad kunskap. Pedagogik uppfattades under lång tid som en fråga om påverkansprocesser och inlärning. Under 1960-talet och framåt tillkom ett ökat intresse för läroplansteori och undervisningsprocesser, och en utveckling av specialpedagogik som område. En kraftig expansion av både forskning och utbildning $\mathrm{i}$ ämnet pedagogik ägde rum. Tidigare forskningsinriktningar kompletterades med nya. Forskningen som fokuserade individ- och 
metodvariabler kompletterades med mer processinriktade studier av undervisning, som $\mathrm{i}$ stor utsträckning gällde ramarnas betydelse för undervisningsprocessen. Det handlade i stor utsträckning om klassrumsstudier av undervisningsprocesser. Komparativa studier av undervisning $\mathrm{i}$ olika länder var också ett område som växte till.

Inom den pedagogiska psykologin skedde en markant förändring från dominans för behavioristiska ansatser till kognitiva. Denna förändring innebar en helt förändrad fokus från yttre beteenden till tankeprocesser. Den kognitivt inriktade forskningen var delvis inspirerad av analogier med datorer. En annan del av den kognitiva forskningen innebar ett återknytande till tidigare tankepsykologi. Särskilt kom Piagets arbeten få stor betydelse inom denna inriktning (se Inhelder \& Piaget, 1958). Den kognitiva inriktningen kombinerades med fokus på tänkandets och undervisningens innehåll och fick särskilt stor betydelse för studier av lärande och undervisning inom naturvetenskapliga ämnen. Den kognitiva inriktningen utmanades av och kompletterades med en sociokulturell inriktning som kritiserade den starka betoningen på inre processer och betonade språkanvändning och kommunikativa processer (se Säljö, 2000). Denna inriktning fokuserade på en större helhet av undervisning och lärande med betoning på de yttre betingelserna för lärande.

\section{Ökande fokus på innehåll}

Tiden från 1970-talet och framåt innebar en omprövning av de vetenskapsteoretiska och metodologiska grunderna för pedagogisk forskning. Den tidigare starka dominansen för kvantitativa metoder bröts och en relativt omfattande kvalitativt inriktad och beskrivande forskning växte fram. I Sverige skedde också en återknytning till kontinentala traditioner som fenomenologi och hermeneutik. En kritik av den pedagogiska psykologins starka dominans framfördes och en del pedagogiska forskare betonade pedagogikämnets närhet till sociologin snarare än psykologin och inspirerades av utbildningssociologisk forskning. Utvecklingen innebar mer av samhällsteoretiska perspektiv och en breddning av den pedagogiska forskningen.

Som en reaktion på den variabelbaserade och den processinriktade forskningen följde en ökad betoning av pedagogikens innehåll och sammanhang. En utveckling från beskrivningar av pedagogik i termer av process och produkt till fokus på innehåll och sammanhang i flera olika perspektiv ägde rum (Dunkin \& Biddles, 1974). I Sverige blev två kunskapsfält särskilt framträdande: forskning om utbildningsverksamhet i linje med internationell "curriculumforskning" och forskning om undervisning och lärande (Rosengren \& Öhngren, 1997). Den stärkta samhällsteoretiska inriktningen, i kombination med fokuseringen på pedagogikens innehåll, kombinerades med ett ökat intresse för historiska studier. Betoningen av ämnesinnehåll har kombinerats med en ökad betoning 
av praktiknära forskning, som också har lett till förnyat intresse för didaktiken, eftersom denna i ett sammanhang behandlar frågor om både undervisningens grund, innehåll och form.

\section{Utvecklingens riktning}

Den här beskrivna utvecklingen och förändringen i kunskapsteoretisk syn och forskningsmetodologisk ansats är det som särskilt uppmärksammas i denna artikel. Utvecklingen har inneburit en utveckling mot mer fallbaserad forskning och en viktig diskussion om fallbaserad forskning på 2000-talet. Flyvbjerg (2006) argumenterar att för viktiga forskningsuppgifter inom socialvetenskaperna är fallstudier en nödvändig och tillräcklig metod, och att bra forskning inte är metoddriven utan problemdriven. Ruddin (2006) argumenterar för att fallstudier möjligen är den grundläggande vetenskapliga metoden. Hesse-Biber (2010) argumenterar för att det viktiga med fallstudier är att de fokuserar vad som undersöks. Thomas (2010) argumenterar med Stake (2005) att fallstudier inte är en metodologi utan ett val av vad som skall undersökas och att fallen måste ses i sin kontext. Svensson \& Doumas (2013) ger en utförligare beskrivning av denna diskussion.

Utvecklingen av den pedagogiska forskningen har inneburit en ökande betoning på pedagogiska fenomen som helheter och på att olika delar av ett fenomen för sin innebörd är beroende av fenomenet som helhet och det sammanhang som fenomenet ingår i. Detta till skillnad från att delar av fenomen definieras som variabler och variabelvärden oberoende av fenomenet som helhet och dess sammanhang. Även om det har skett en utveckling av det slag som framhålls här har tydligheten i avgränsning av pedagogiska fenomen som kunskapsobjekt, och av delar av dessa fenomen som just delar och inte allmänt definierade enheter, inte varit så stor som är önskvärt. Detta är en brist som handlar om pedagogikens principiella avgränsning, som behandlas i nästa avsnitt.

\section{PEDAGOGIKENS AVGRÄNSNING OCH BESTÄMNING}

Detta avsnitt handlar om hur man i princip kan avgränsa och bestämma vad som är pedagogiska fenomen och undersökningsobjekt. Anledningen till detta fokus är den oklarhet som har rått historiskt, så som påtalats ovan. Man har talat om pedagogik, uppfostran, undervisning och utbildning. De aktiviteter och verksamheter som betecknas med dessa begrepp är komplexa och omfattar många inslag och aspekter. Dessa aktiviteter och verksamheter kan beskrivas från många olika perspektiv. Frågan är vad det innebär att beskriva dem som pedagogiska. Det kan tyckas vara självklart, att det första man bör göra i en undersökning av något, är att klargöra vad det är man undersöker. Det har man naturligtvis också gjort i den pedagogiska forskningen. Det som 
har varit oklart är på vilket sätt det man undersöker utgör pedagogiska fenomen.

Den empiriska forskningen har tagit sin utgångspunkt ifrån praktiska uppfostrings-, undervisnings- och utbildningssituationer. Frågor och problem har formulerats utifrån inslag i de aktiviteter och verksamheter som finns $i$ dessa situationer. Om och på vilket sätt dessa frågor, problem och inslag handlar om pedagogik har ofta varit oklart. Utgångspunkten från variabler har på ett särskilt sätt gjort det oklart vilka fenomen som undersöks och som variabelvärden tänks gälla delar av. Mot denna bakgrund framhålls här behovet av fallbaserade undersökningar utifrån ett kontextuellt tänkande. Fallen tänks vara lika med fall av pedagogiska fenomen och lika med huvudsakliga pedagogiska undersökningsobjekt (jmf Flyvberg, 2006; Ruddin, 2006; Stake 2005; Svensson \& Doumas 2013; Thomas, 2010).

Den fallbaserade forskning som förordas här är inte lika med klassiska fallstudier. Dessa brukar karakteriseras av att man har ett eller mycket få fall som är mycket allmänt bestämda som fall och som beskrivs på ett omfattande och så uttömmande sätt som möjligt. Fallbaserade studier gäller här inte denna typ av omfattande beskrivningar i mycket breda eller obestämda perspektiv. Fallbaserad innebär här att man har ett antal undersökningsobjekt som man undersöker som helheter - fall, utifrån en tydlig avgränsning i ett teoretiskt perspektiv, $i$ vårt fall ett pedagogiskt perspektiv. Detta kan främst ses i motsats till variabelbaserade undersökningar, där antingen vad som skulle vara fall som undersöks är oklart, eller där bearbetning och sammanställning av data och slutsatser görs över fall på gruppnivå, och inte fall för fall som helheter. Den grundläggande skillnaden är hur man tolkar, grupperar och sammanställer data. En fallbaserad analys utesluter inte användning av variabler. Skillnaden handlar om hur variabelvärden ges innebörd och sammanställs.

Det är grundläggande i en fallbaserad undersökning att fallen motsvarar de fenomen som undersöks. Miles och Huberman (1994) ser fall som de grundläggande enheterna vid forskning och grupperar sätt att samla in och ordna empiriska data i två huvudkategorier, variabelbaserade och fallbaserade sätt. Den pedagogiska forskningen behöver vara fallbaserad och fallen lika med undersökningsobjekten. Ett huvudskäl till denna ståndpunkt är vikten av klarhet om vad som undersöks och vad resultaten begränsas till och gäller. Ett andra skäl är behovet av att tolka individuella data inom kontexten av undersökta fall som helheter. En utmaning blir då att avgränsa undersökta fall vid insamling och bearbetning av empiriska data. Undersökningar behöver vara fallbaserade utifrån en tydlig avgränsning av pedagogiska fall.

\section{Pedagogikens kunskapsobjekt}

Pedagogik handlar om vad som utgör den uppfostrande, undervisande och utbildande karaktären, och därmed den pedagogiska karaktären, hos 
aktiviteter och verksamheter. Sådana aktiviteter och verksamheter, som till exempel de i ett klassrum, kan beskrivas på många olika sätt och som fenomen inom olika discipliner och kunskapsområden. Man kan till exempel beskriva känslomässiga inslag och kvaliteter i klassrumsinteraktionerna som ett socialpsykologiskt fenomen, turtagning i kommunikationen som ett språkpragmatiskt fenomen, maktutövning som ett mikropolitiskt fenomen och så vidare. Dessa fenomen, och fler, kan beskrivas i sig som delar av olika kunskapsområden som psykologi, språkvetenskap sociologi, statsvetenskap med flera. Dessa inslag och kvaliteter som fokuseras kan också ses som delar av pedagogiska fenomen och förstås och beskrivas utifrån hur de ingår i pedagogiska fenomen och kunskapsobjekt. I det följande lyfts några viktiga val fram, när det gäller avgränsning av pedagogiska kunskapsobjekt.

\section{Avsikt och funktion}

Pedagogik riskerar att avgränsas till att handla om pedagogers avsiktliga, planerade och målinriktade handlande. En sådan avgränsning grundas i vad pedagogen gör. Det centrala är emellertid den funktion som det har, som pedagogen gör. Funktionen handlar om hur avsikten genomförs och med vilket resultat. Det centrala är den uppfostrande, undervisande och utbildande funktionen. Funktionen visar sig i aktivitetens och verksamhetens resultat. I de verksamheter som kallas för pedagogiska finns både en avsikt och en funktion. Den avsikt som finns är naturligtvis viktig. Medvetenheten om vad man vill göra, och vad det är man gör, är avgörande för utformning och förbättring av pedagogisk aktivitet och verksamhet. Denna medvetenhet behöver vara en medvetenhet om aktiviteters och verksamheters pedagogiska funktion.

\section{Lärande som förändring av relationen till omvärlden}

Den pedagogiska funktionen uppfylls genom lärande. När det här talas om den lärande kan det vara en individ, en grupp och/eller ett samhälle, som är den lärande. Möjligheten till lärande är en förutsättning för pedagogik, men pedagogik handlar inte om alla förekommande innebörder i lärande. Inom pedagogiken är fokus på lärandets innehåll, och förutsättningarna för att detta innehåll skall uppstå och förändras. Det handlar om innehåll och kvaliteter i sätt att tänka, känna, vilja och handla i förhållande till omvärlden. Det är vissa aspekter och kvaliteter hos ett subjekts relation till omvärlden som uppmärksammas. Det finns tre huvudaspekter när det gäller innehållet i relationen: en kunskapsmässig (veta), en färdighetsmässig (kunna utföra) och en värderingsmässig (vilja). Den känslomässiga aspekten finns också med men fokuseras inte på samma sätt som pedagogiskt innehåll. Det handlar om kvaliteter inom dessa aspekter och hos dem tillsammans på olika sätt. Lärande handlar om förändringar i dessa aspekter och kvaliteter hos individers, gruppers och samhällens relation till sin omvärld och till sig själva. Denna förändring är en följd av påverkan från omvärlden och den lärandes aktivitet. 
Den lärandes aktivitet utgör lärandets närmaste sammanhang. Det yttre sammanhangets betydelse för lärandet är beroende av den lärandes aktivitet (se Marton, 2015).

\section{Stöd till lärande}

Att bereda möjlighet till lärande är en pedagogisk fråga och bland annat en fråga om vilket innehåll som skall göras tillgängligt och i vilka former. Kunskap om lärande är avgörande för synen på vad som utgör stöd till lärande. Stödet har miljökaraktär i förhållande till lärandet och handlar om vad som utgör lärandemiljö sett utifrån det lärande som äger rum. Vad som är lärandemiljö bestäms både av den yttre miljöns erbjudna möjligheter och av den lärandes användning av dessa möjligheter. Stöd till lärande, som en del av pedagogikens kunskapsobjekt, handlar om det i miljön som den lärande använder för att lära. Varje lärande utgör sitt eget sammanhang, när det gäller innebörden hos olika pedagogiska handlingar och erbjudanden från miljön. Eftersom det är denna innebörd för den lärande, som är mest direkt relaterad till lärandeaktivitet och resultat, finner vi ingen generell relation mellan pedagogiska metoder och pedagogiska resultat över lärande och situationer. Vi behöver förstå pedagogiska handlingar och pedagogisk miljö som stöd till lärande. Pedagogiska fenomen och kunskapsobjekt har två huvuddelar: stöd till lärande och lärande med fokus på lärandets innehåll (se Svensson, 2014).

\section{Kontextuellt tänkande om kunskapsobjekten}

Ett kontextuellt tänkande om pedagogiska fenomen innebär en utgångspunkt i ett urskiljande och avgränsning av sådana fenomen. Detta kräver en teoretisk utgångspunkt i förståelsen av vad som är pedagogiska fenomen. Här har föreslagits att pedagogiska fenomen utgörs av relationen mellan stöd till lärande och lärande. Det kontextuella tänkandet består i att sådana fenomen ses som beroende av sina sammanhang samtidigt som de urskiljs i sina sammanhang som enheter i sig. Ännu viktigare i det kontextuella tänkandet är att delar av de pedagogiska fenomenen tolkas och förstås som beroende av hur de ingår i den helhet som fenomenet utgör. Detta innebär att innebörden hos en enhet som motsvarar en del av ett fenomen inte kan bestämmas oberoende av hur den delen är relaterad till fenomenets övriga delar och helhet och dess sammanhang.

\section{Pedagogikens kunskapsområde}

I samband med den empiriskt variabelbaserade inriktning, som dominerade den pedagogiska forskningen vid expansionen av denna under 1950- och 1960-talen, fanns det en tendens att se pedagogik som ett helt och hållet flervetenskapligt område. Mot denna syn har stått en uppfattning av pedagogik som ett eget kunskapsområde. Samtidigt har det mesta av den pedagogiska forskningen inte utgått från en helhetsuppfattning av pedagogik utan fokuserat på relativt avgränsade problem. Här föreslås att pedagogik bör 
ses som ett eget kunskapsområde utifrån att det behandlar pedagogiska kunskapsobjekt, så som föreslagits ovan (se även Svensson, 1996). Detta är ett mycket stort kunskapsområde, som är svårt att rymma inom en begränsad enskild disciplin. Det är ett kunskapsområde som både historiskt och principiellt har fått stöd från och gränsar till andra discipliner.

Det finns delar av pedagogik som både historiskt och principiellt gränsar till teologi, filosofi, psykologi, antropologi, sociologi, statsvetenskap, ekonomi med flera. Sedan har vi det förhållandet att pedagogiken har gränsområden till alla de kunskapsområden, teoretiska och praktiska, som utgör utgångspunkter för pedagogikens innehåll. Dessa områden utgör vad som kallas ämnespedagogik eller ämnesdidaktik. Pedagogiken delar fokus på olika aspekter med många andra discipliner. Skillnaden är om dessa aspekter fokuseras som innehåll i pedagogiska fenomen och kunskapsobjekt eller på andra sätt. Utifrån ett kontextuellt tänkande är det avgörande inom vilken helhet man betraktar aspekterna, och att vi är tydliga med hur de ingår i pedagogiska kunskapsobjekt. Det är genom en kontextuell förståelse av pedagogiska kunskapsobjekt som det pedagogiska kunskapsområdet kan avgränsas från och relateras till andra kunskapsområden, som berör överlappande delar av verkligheten.

Olika relativt omfattande delar av pedagogikens kunskapsområde representeras av pedagogisk filosofi, didaktik, pedagogikens historia, pedagogisk psykologi och komparativ pedagogik. Det finns också tydligt urskiljbara delar av området utifrån vilka åldersgrupper och delar av utbildningssystemet och samhället som de gäller. Exempel på detta är specialpedagogik för grupper med särskilda behov, idrottspedagogik, förskolepedagogik, högskolepedagogik och arbetslivspedagogik. Inom alla dessa ovan nämnda specialområden finns det en kumulativ kunskapsbildning som presenteras i vetenskapliga skrifter och i stor utsträckning också i internationella vetenskapliga tidskrifter.

Tanken här är alltså att pedagogikens kunskapsområde bäst avgränsas utifrån vilka kunskapsobjekt som utgör området. Det förslag till syn på pedagogik som getts här, koncentrerat till bestämning av pedagogikens kunskapsobjekt, innehåller först en fokus på lärande, som en förutsättning för förekomsten av pedagogik. Pedagogikens mångfald beskriven i samhälls-, grupp-, individ- och kulturperspektiv behöver knytas till dess funktion när det gäller individers, gruppers och samhällens lärande. Insatser för uppfostran, undervisning och utbildning behöver relateras till konsekvenser $\mathrm{i}$ form av lärande. Till skillnad från den psykologiska traditionens fokus på individer och inre processer föreslås en syn på lärande, som innebär att lärande är en förändring i den lärandes (individ, grupp eller samhälle) relation till en del av världen. Förändringen bestäms av den lärandes aktivitet och av den del av världen aktiviteten riktas mot. Aktiviteten i sin tur bestäms av både inre och yttre betingelser. 
Det är lärandeaktivitetens beroende av de yttre betingelserna som gör stöd till lärande möjligt och viktigt. Till skillnad från dominans för betoning av och fokus på påverkan, förmedling, kontroll och metoder, med antaganden om att dessa direkt leder till önskade resultat, föreslås fokus på den lärande som aktiv, och den som slutligt bestämmer lärandets process, innehåll och utfall. Det är genom stöd till den lärandes aktivitet, som det är möjligt att inrikta lärandet mot önskat innehåll och önskade mål. Detta gör att avsiktligt stöd genom utformning av miljön och särskilt genom lärarinsatser är avgörande $i$ pedagogiken. De mest utmanande och centrala pedagogiska frågorna att besvara gäller hur relationer mellan pedagogiska insatser och lärande konstitueras, och hur de kan utformas för att leda till önskade resultat i individ-, grupp-, samhälls- och kulturperspektiv (se Marton, 2015; Svensson, 2014).

\section{Pedagogikens institutionella inramning}

Pedagogik har utvecklats till ett omfattande vetenskapligt kunskapsområde. Vid utländska universitet representeras området i stor utsträckning av en enhet kallad "School of Education" eller en "Faculty of Education". I Sverige har pedagogik under lång tid varit ett sammanhållet universitetsämne som $\mathrm{i}$ huvudsak varit placerat inom samhällsvetenskapliga fakulteter. Detta är principiellt ingen självklarhet med tanke på ämnets karaktär av kulturvetenskap snarare än psykologi eller samhällsvetenskap. På senare tid har utbildningsvetenskap tillkommit som ett flitigt använt begrepp i Sverige. Skälet är att Vetenskapsrådet har inrättat ett vetenskapsområde som kallas utbildningsvetenskap (Askling, 2000; Fransson \& Lundgren, 2003). Inrättandet av och benämningen av detta område motiverades av ett samhälleligt behov av mer kunskap om utbildning, särskilt som grund för lärarutbildning och lärarverksamhet. Det är något oklart hur utbildningsvetenskap förhåller sig till pedagogik som vetenskap, även om det rimligen finns en mycket stor överlappning mellan begreppen och områdena (se Svensson, 2014).

Både den internationella situationen och tillkomsten av utbildningsvetenskap understryker att pedagogik är ett omfattande vetenskapsområde. Det gör också den omfattande specialiseringen inom pedagogik som område. Vad som framstår som av största vikt är att pedagogikens principiella karaktär $\mathrm{i}$ form av kunskap om pedagogikens kunskapsobjekt blir tydlig. Det främsta skälet till detta är att de pedagogiska fenomenen och kunskapen om dem har en avgörande individuell och samhällelig betydelse. En ökad klarhet om de pedagogiska kunskapsobjekten och det pedagogiska kunskapsområdet kan också göra relationen till angränsande kunskapsområden mer fruktbar. 


\section{SAMMANFATTNING}

I denna artikel har beskrivits hur pedagogiken gick från att vara en del av filosofiskt och teologiskt tänkande till att bli en empiriskt grundad vetenskap. Det filosofiska och teologiska tänkandet hade också en empirisk grund i form av erfarenheter och observationer av praktisk pedagogisk verksamhet. Sådana erfarenheter och observationer underordnades filosofiska och teologiska tankesystem, vilka var de som uppfattades som väsentlig kunskap. Det empiriska vetenskapliga arbetet utgick däremot från observationer och systematiska sammanställningar av observationer, som den väsentliga grunden för kunskapsbildningen. Det vetenskapliga arbetet handlade om väl avgränsade undersökningar av specifika empiriska fenomen och problem. Kunskapsbildningen förväntades vara kumulativ och byggas upp genom att den ena empiriska undersökningen efter den andra lades samman. Denna ansats ger möjlighet till ett kontextuellt tänkande om de pedagogiska fenomenen, det vill säga att förstå de specifika fenomenen och observationerna i sin egenart i sitt specifika sammanhang.

Skillnaden mellan variabelbaserade och fallbaserade undersökningar har lyfts fram som en väsentlig skillnad i den empiriska vetenskapliga pedagogiska forskningen. Den tidiga empiriska forskningen var i stor utsträckning variabelbaserad. Detta innebar att enskilda observationer i första hand tolkades så som de ingick som variabelvärde i en generellt definierad variabel och inte $\mathrm{i}$ förhållande till det fenomen de utgjorde en del av. Detta kombinerades i sin tur med en oklarhet om vilket pedagogiskt fenomen som undersöktes. Detta innebar ett icke-kontextuellt tänkande både när det gällde förståelse av enskilda observationer och förståelse av pedagogiska fenomen. Den lösning på detta problem som förslås här är fallbaserade undersökningar inom ramen för ett kontextuellt tänkande. Vid en fallbaserad ansats blir det viktigt vad som utgör ett fall. Här föreslås att fall i den pedagogiska forskningen bör vara lika med pedagogiska fenomen som kunskapsobjekt. En sådan ansats kräver klargöranden av vad som utgör pedagogiska fenomen och problem, som utgångspunkt för forskningen.

Med utgångspunkt från att lärande som fenomen är en förutsättning för all pedagogik har stöd till lärande föreslagits som den principiella karaktären hos all pedagogik. Alla pedagogiska fenomen och problem gäller relationen mellan stöd till lärande och lärande. Vad som är stöd behöver avgöras utifrån vad som används för att lära. Det är när insatser och erbjudanden från lärare och i och genom den lärandes miljö används för att lära, som de får funktionen av att vara stöd till lärande. Det är först när det som är avsett som stöd till lärande beskrivs till sin funktion, sin relation till faktiskt lärande, som vi beskriver ett pedagogiskt fenomen. Sådana pedagogiska fenomen av helheter av stöd till lärande och lärande behöver beskrivas och förstås, och kan vara av mycket olika omfattning och karaktär vad gäller innehåll och sammanhang. De kan beskrivas för individer, grupper och samhällen. 
Det är pedagogikens kunskapsobjekt som tillsammans utgör pedagogikens kunskapsområde. Etablerade beskrivningar av dessa kunskapsobjekt utgör pedagogik som ämne och disciplinärt kunskapsområde. Som sådant kunskapsområde har ämnet hämtat mycket stöd från många angränsande ämnen på olika sätt, beroende på vilka specifika fenomen och problem som har undersökts. Detta har också avspeglats i en varierande institutionell inramning. Inom det kontextuella tänkande om pedagogik, som förordas här, blir det viktigt att bestämma pedagogikens kunskapsområde utifrån pedagogikens kunskapsobjekt. Utifrån bestämningen av kunskapsobjekt kan vi klargöra avgränsningar och relationer till andra ämnen och kunskapsområden. Pedagogiken behöver förstås som helheter av fall av relationen mellan stöd till lärande och lärande. Fallens innebörd behöver förstås som beroende av fallens sammanhang, och innebörden hos delar av fallen behöver förstås som beroende av helheten av de fall de utgör en del av, det vill säga inom ramen för ett kontextuellt tänkande.

\section{REFERENSER}

Askling, B. (2000). Utbildningsvetenskap: Ett vetenskapsområde tar form. Stockholm: Vetenskapsrådets rapportserie 16.

Bracht, G. H. (1970). Experimental factors related to aptitude-treatment interaction. Review of Educational Research, 40(5), 627-645.

Comenius (1989). Didactica Magna. Stora undervisningsläran. Göteborg: Daidalos.

Cronbach, L. J. (1957). The two disciplines of scientific psychology. American Psychologist, 12(11), 671-684.

Dunkin, M. J. \& Biddle, B. J (1974). The study of teaching. New York: Holt, Rinehart and Winston.

Flyvbjerg, B. (2006). Five misunderstandings about case study research. Qualitative Inquiry, 12(2), 219-245.

Fransson, K. \& Lundgren, U. P. (2003). Utbildningsvetenskap: Ett begrepp och dess sammanhang. Stockholm: Vetenskapsrådets rapportserie 2003:1.

Gage, N. L. (Red.) (1963). Handbook of research on teaching. Ill.: Rand McNally.

Herbart, J. F. (1917). Konturer till föreläsningar i pedagogik. Stockholm: Bonniers.

Hesse-Biber, S. (2010). Qualitative approaches to mixed methods practice.

Qualitative Inquiry, 16(6), 455-468.

Inhelder, B. \& Piaget, J. (1958). The growth of logical thinking from childhood to adolescence. London: Routledge \& Kegan Paul Ltd.

Kroksmark, T. (2011a). Den tidlösa pedagogiken. Lund: Studentlitteratur. 
Kroksmark, T. (2011b). Didaktiska strövtåg. Göteborg: Daidalos.

Kuhn, T. S. (1962/1970). The structure of scientific revolutions. Chicago: University of Chicago Press.

Kuhn, T. S. (1970). Reflections on my critics. I I. Lakatos \& A. Musgrave (Red.). Critisicm and the growth of knowledge (s. 231-278). Cambridge: Cambridge University Press.

Kuhn, T. S. (1974). Second thoughts on paradigms. I F. Suppe (Red.). The structure of scientific theories (s. 459-517). Urbana: University of Illinois Press.

Landquist, J. (1963). Pedagogikens historia. Lund: Gleerups.

Lindberg, G. \& Lindberg, L. (1983). Pedagogisk forskning i Sverige 1948-1971. En explorativ studie av inom - och utomvetenskapliga faktorer. Umeå: Samhällsvetenskapliga fakulteten, Umeå universitet.

Lindberg, L. \& Berge, B-M. (Red.) (1988). Pedagogik som vetenskap - vetenskap som pedagogik. Lund: Studentlitteratur.

Marton, F. (2015). Necessary conditions of learning. New York: Routledge.

Masterman, M. (1970). The nature of a paradigm. I I. Lakatos \& A. Musgrave (Red.). Criticism and the growth of knowledge (s. 59-89). Cambridge: Cambridge University Press.

Miles, M. B. \& Huberman, A. M. (1994). Qualitative data analysis. An expanded sourcebook. Thousand Oaks: SAGE Publications.

Myhre, R. (1967). Pedagogisk idéhistorie. Oslo: Fabritius \& Sönners förlag.

Myhre, R. (1988). Grunnlinjer i pedagogikekens historie. Oslo: Gyldendal Nors Forlag.

Popper, K. R. (1959). The logic of scientific discovery. London: Hutchinson and Co.

Popper, K. R. (1963). Conjectures and refutations: The growth of scientific knowledge.

London: Routledge and Kegan Paul.

Radnitzky, G. (1970). Contemporary schools of metascience. Vol I-II. Göteborg: Akademiförlaget.

Richardson, V. (Red.) (2001). Handbook of research on teaching. Washington, D. C.: American Educational Research Association.

Richardson, G. (2004). Svensk utbildningshistoria. Skola och sambälle förr och nu. Lund: Studentlitteratur.

Rosengren, K-E. \& Öhngren, B. (Red.) (1997). An evaluation of Swedish research in education. Stockholm: HSFR.

Ruddin, L. P. (2006). You can generalize stupid! Social scientists, Bent Flyvbjerg, and case study methodology. Qualitative Inquiry, 12(4), 797-812.

Sandström, C. I. (1975). Utbildningens idébistoria. Stockholm: Aldus. 


\section{LENNART SVENSSON}

Sjöstrand, W. (1954). Pedagogikens historia. 1, Frän antiken till första världskriget. Lund: Gleerups.

Sjöstrand, W. (1954-1965). Pedagogikens historia. Del I-III:2. Lund: C.W. K. Gleerups förlag.

Sjöstrand, W. (1969). Pedagogiska grundproblem i historisk belysning. Lund: Gleerups.

Stake, R. E. (2005). Qualitative case studies. I N. K. Denzin \& Y. S. Lincoln (Red.). The Sage handbook of qualitative research (3. uppl.) (s. 443-466). Thousand Oaks: Sage.

Svensson, L. (1976). Study skill and learning. Göteborg: Acta Universitatis Gothoburgensis.

Svensson, L. (1996). Pedagogiken som vetenskap! Pedagogisk forskning i Sverige, 1(2), 106-108.

Svensson, L. (2004). Forskningsmetoders analytiska och kontextuella kvaliteter. I C. M. Allwood (Red.). Perspektiv på kvalitativ metod (s. 65-95). Lund: Studentlitteratur.

Svensson, L. (2014). Introduktion till pedagogik. Lund: Studentlitteratur.

Svensson, L. \& Doumas, K. (2013). Contextual and analytic qualities of research methods exemplified in research on teaching. Qualitative Inquiry, 19(6), 441-450.

Säljö, R. (2000). Lärande i praktiken. Ett sociokulturellt perspektiv. Stockholm: Prisma.

Thomas, G. (2010). Doing case study: Abduction not induction, phronesis not theory. Qualitative Inquiry, 16(7), 575-582.

Travers, R. M. W. (Red.). Handbook of research on teaching. Chicago: Rand McNally.

Törnebohm, H. (1975). Inquiring systems and paradigms. Göteborg: University of Göteborg, Reports from the Department of Theory of Science, no 72.

Törnebohm, H. (1977a). Kontexuellt tänkande. Göteborg: Göteborgs universitet, Avdelningen för Vetenskapsteori, rapport nr 89.

Törnebohm, H. (1977b). Paradigms in fields of research. Göteborg: University of Göteborg, Reports from the Department of theory of Science, no 93.

Wittrock, M. C. (Red.) (1986). Handbook of research on teaching. New York: Macmillan Publishing Company.

Ödman, P-J. (1987). Konformismens triumf. Utvecklingslinjer i svensk 1600-talspedagogik. Stockholm: Pedagogiska institutionen, Stockholms universitet.

Ödman, P-J. (1990). Tid av fribet tid av tvaing. Utvecklingslinjer i svensk 1700-talspedagogik. Stockholm: Pedagogiska institutionen, Stockholms universitet.

Ödman, P-J. (1995). Kontrasternas spel - En svensk mentalitets- och pedagogikhistoria. Stockholm: Norstedts. 